\title{
Nucleic Acid Synthesis and Nucleotide Pools in Purine-Deficient Escherichia coli
}

\author{
BY GILLIAN A. THOMAS,* N. F. VARNEY AND K. BURTON \\ Department of Biochemistry, University of Newcastle upon Tyne, Newcastle upon Tyne \\ $N E 17 R U, U . K$.
}

(Received 26 May 1970)

\begin{abstract}
1. The synthesis of nucleic acids and the content of purine nucleotides have been studied in selected purine-requiring strains of Escherichia coli including a purBstrain and a purB- guaA- strain. 2. When the exogenous purines can be converted into GTP but not into ATP, RNA is synthesized at the expense of intracellular ATP, ADP and AMP. 3. Net synthesis of RNA as measured by the incorporation of uracil can be correlated with the availability of GTP except when ATP falls to a very low concentration. 4. Nicotinamide nucleotides are not an important reservoir of adenine nucleotides for RNA synthesis.
\end{abstract}

In growing cells, the utilization of ATP and GTP for net synthesis of RNA must to some extent compete with other functions of these nucleotides in energy metabolism and biosynthesis. Indirect evidence indicates that nucleic acid synthesis is halted by purine deficiency before certain important pathways of metabolism are seriously affected. For example, Pardee (1955) found that, after allowance for the effect on cell multiplication, adenine deficiency did not affect the rate of glucose oxidation by an adenine auxotroph of Escherichia coli. Also, intermediates of purine biosynthesis may accumulate when adenine is withdrawn or exhausted (Gots, 1957; Gots \& Goldstein, 1959) despite the fact that their synthesis requires ATP.

In this and the following paper we ask what mechanisms limit the synthesis of RNA in purine deficient $E$. coli and whether there is a physiologically important regulatory mechanism. Part of the work has been presented to the Biochemical Society (Jeffries \& Burton, 1969) and is discussed in a review article (Burton, 1970).

\section{MATERIALS AND METHODS}

Bacteria and media. Details of the strains are given in Table 1. Cultures were normally grown with aeration in a $1 \%$ glucose medium with inorganic salts as used by Stone \& Burton (1962) and supplemented with appropriate growth requirements at the following concentrations: adenine and guanosine, $10 \mathrm{mg} / 1$; L-proline, $30 \mathrm{mg} / \mathrm{l}$; thiamin hydrochloride, $1 \mathrm{mg} / 1$. L-Histidine hydrochloride $(10 \mathrm{mg} / \mathrm{l})$ was added to all media, whether or not it was required, to repress and inhibit the enzymes of histidine biosynthesis. Guanosine was used in preference to

* Present address: Nuffield Department of Biochemistry, Radcliffe Infirmary, Oxford OX2 6HE, U.K. guanine because it gave higher growth rates and because it was incorporated more rapidly. The growth and the subsequent experiments were performed at $25^{\circ} \mathrm{C}$. Growth was followed by reading the $E_{620}$ in a Hilger Spectrochem spectrophotometer, which was converted into total cell counts (no. of cells per litre $=E_{620} \times 8 \times 10^{11}$ or, for strain NE-1, $\left.E_{620} \times 1.1 \times 10^{12}\right)$. Unless otherwise stated cultures $\left(2-5 \times 10^{11}\right.$ cells/1) were harvested by centrifuging at $3^{\circ} \mathrm{C}$, and were washed twice with glucose-free minimal medium before resuspension. As a routine, portions of the cultures were tested for reversion of the purine requirements.

Acid-insoluble radioactivity. Samples were taken into $5 \%(w / v)$ trichloroacetic acid at $0^{\circ} \mathrm{C}$, filtered on Oxoid membrane filters after $20 \mathrm{~min}$, and washed with ice-cold $\mathbf{5} \%(w / v)$ trichloroacetic acid. The filters were dried and radioactivity was usually measured by scintillation counting in a toluene-dioxan scintillation fluid (Herberg, 1960 ) in a Beckman LS-200 instrument.

Nucleic acids. Except in the experiment of Fig. 4, incorporation of uracil into DNA was measured in $0.5 \mathrm{ml}$ culture samples which were added to $0.5 \mathrm{ml}$ of $\mathrm{M}-\mathrm{KOH}$ and incubated at $37^{\circ} \mathrm{C}$ for $18 \mathrm{~h}$. Bovine plasma albumin $(100 \mu \mathrm{g})$ was then added, followed by $5.3 \mathrm{ml}$ of ice-cold $10 \%(\mathrm{w} / \mathrm{v})$ trichloroacetic acid. The acid-insoluble material was collected on cellulose nitrate filters with $0.45 \mu \mathrm{m}$ pore size (Sartorius-Membranfilter G.m.b.H., 34, Göttingen, W. Germany) and radioactivity was measured in $5 \mathrm{ml}$ of toluene containing $3 \mathrm{~g}$ of 2,5-diphenyloxazole/1 and $0.1 \mathrm{~g}$ of 1,4-bis-(5-phenyloxazol-2-yl)benzene/1. The incorporation into RNA was determined by subtracting the radioactivity in DNA from the total acid-insoluble radioactivity measured on similar filters and by the same counting procedure.

Purine nucleotide pools. Cultures were grown in the presence of radioactive purines as described in the text. Samples were taken into 5 vol. of $5 \%(w / v)$ trichloroacetic acid at $0^{\circ} \mathrm{C}$, centrifuged after $20 \mathrm{~min}$ and the precipitate was washed with 1 vol. of $5 \%(w / v)$ trichloroacetic acid. The washing and supernatant were combined and most of the acid was extracted by shaking with three successive portions of diethyl ether, a total of 30 times 
Table 1. Purine-requiring mutants of E. coli

\begin{tabular}{|c|c|c|c|c|}
\hline Strain & Origin & Parent & Description & purine biosynthesis \\
\hline B-96 & J. S. Gots & B & pur $H^{-}$ & $\begin{array}{l}\text { 5-Amino-4-imidazole- } \\
\text { carboxamide ribo- } \\
\text { nucleotide } \rightarrow \text { IMP }\end{array}$ \\
\hline AB-1325 & A. L. Taylor & $\mathrm{K} 12$ & 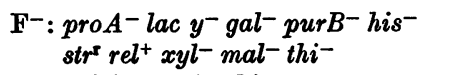 & Adenylosuccinase \\
\hline AT-2465 & A. L. Taylor & $\mathrm{K} 12$ & $H$ fr $H$ guaA- thi- & XMP aminase \\
\hline NE-1 & This laboratory & AB-1325 $\times$ AT- 2465 & $\begin{aligned} & \mathrm{F}^{-} \text {proA }^{-} \text {lac } y^{-} \text {gal- }^{-} \text {pur } B^{-} \text {guaA } \\
& \\
& \text { str }^{-} \text {rel }^{+} x y l^{-} \text {mal- } \\
& \text { thi- }\end{aligned}$ & $\begin{array}{l}\text { Adenylosuccinase and } \\
\text { XMP aminase }\end{array}$ \\
\hline
\end{tabular}

the volume of the combined washings and supernatant being used. The remaining aqueous layer was freeze-dried and the residue was dissolved in water of the same volume as the original sample of culture. Together with nonradioactive marker nucleotides (ATP, ADP, AMP, GTP, GDP, GMP, NAD and NADP), 50 or $100 \mu 1$ was applied near a corner of a sheet of Whatman no. 1 filter paper $(47 \mathrm{~cm} \times 57 \mathrm{~cm})$. The paper was sprayed with $0.05 \mathrm{M}$ ammonium formate buffer, pH2.7, containing $1 \mathrm{~mm}$ EDTA, and subjected to ionophoresis in the longer direction until a picric acid marker was about $10 \mathrm{~cm}$ from the farther edge. This required either $1.5 \mathrm{~h}$ at $2.5 \mathrm{kV}$ in a white-spirit-cooled tank or $18 \mathrm{~h}$ at $200 \mathrm{~V}$ in the apparatus of Rushizky \& Knight (1960). The high-voltage procedure was the better method. The sheet was dried and developed with aq. $70 \%(v / v)$ propan-2-ol in the second direction. If ATP and GTP were not separated from each other, a strip carrying these nucleotides was cut off and developed in the second direction with propan-1-olconc. aq. $\mathrm{NH}_{3}$ (sp. gr. 0.88$)$-water $(6: 3: 1$, by vol.). The development with aq. $70 \%(\nabla / \nabla)$ propan-2-ol in the second direction was repeated either for the whole sheet of paper or for the part remaining after the ATP and GTP strip had been cut off. The nucleotides were detected by the u.v. absorption of the marker compounds, the spots were cut out and the radioactivity was measured by liquid-scintillation counting. The values were converted into absolute amounts of nucleotides, by knowing the specific radioactivity of the ${ }^{3} \mathrm{H}$ precursor and the counting rates of filter paper containing known amounts of $\left[{ }^{3} \mathrm{H}\right]$ adenine.

The main radioactive areas coincided with the positions of the marker nucleotides. Any dADP or dGDP in the cultures would be included in the ADP or GDP values but markers of dATP, dGTP, dAMP and dGMP were separated from the corresponding ribonucleotides. The dGTP spot overlapped the ATP area but the amount of dGTP was negligible because no radioactivity was detected in the dGTP area from strain NE-1, labelled with $\left[8-{ }^{3} \mathrm{H}\right]$ guanosine. In any case, since the total amounts of deoxynucleotides have been reported to be only $1-5 \%$ of the ribonucleotides (e.g. Edlin \& Stent, 1969), the incomplete separations from the deoxynucleotides are not expected to introduce appreciable errors into the amounts of the ribonucleotides.

We have, however, observed serious contamination of the ADP and AMP areas in experiments with strain AB-1325 supplied with radioactive hypoxanthine. As expected, radioactivity was found in xanthosine $5^{\prime}$-phosphate, which was not always completely separated from

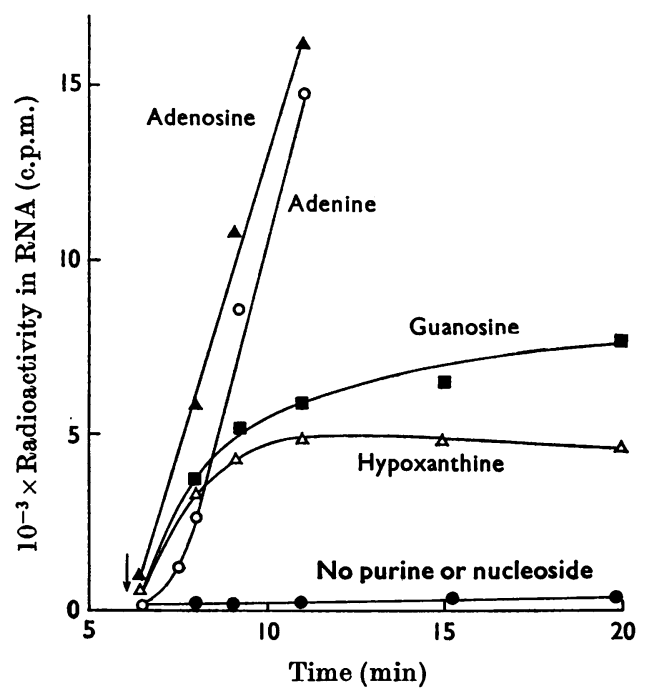

Fig. 1. Effects of various purine sources on the incorporation of uracil into RNA by strain AB-1325 (pur $B^{-}$). A washed exponential culture $\left(2.0 \times 10^{11}\right.$ cells/1) was aerated in purine-free medium at $25^{\circ} \mathrm{C}$. $\left[2-^{14} \mathrm{C}\right]$ Uracil $(19 \mu \mathrm{M} ; 52.5 \mathrm{Ci} / \mathrm{mol})$ was added at $5 \mathrm{~min}$ and adenine $(O)$, adenosine $(\Delta)$, hypoxanthine $(\Delta)$ or guanosine $(\square)$ $(10 \mathrm{mg} / \mathrm{l})$ at $6 \mathrm{~min}$ as indicated by the arrow (๑, no purine or nucleoside added). Sample volumes were $0.5 \mathrm{ml}$.

ADP. An unidentified radioactive contaminant was also found in the AMP area. Nevertheless, when strain NE-1 was fed on $\left[8{ }^{3} \mathrm{H}\right]$ guanosine, no radioactivity was found in the ATP, ADP, AMP, NAD or NADP areas; likewise with this strain no $\left[{ }^{14} \mathrm{C}\right]$ adenine appeared in the GTP, GDP or GMP areas.

Radiochemicals. One batch of $\left[8-{ }^{3} \mathrm{H}\right]$ guanosine was bought from New England Nuclear Corp., Boston, Mass., U.S.A. Other radiochemicals were from The Radiochemical Centre, Amersham, Bucks., U.K., except that $\left[{ }^{3} \mathrm{H}\right]$ hypoxanthine was prepared by treating $\left[2,8{ }^{3} \mathrm{H}\right]$ adenine $(2.598 \mathrm{Ci} / \mathrm{mmol})$ with nitrous acid. The deamination was allowed to proceed for $2 \mathrm{~h}$ at room temperature with $0.25 \mathrm{mCi}$ of adenine, $12.5 \mu \mathrm{l}$ of acetic acid and $6 \mathrm{mg}$ of $\mathrm{NaNO}_{2}$ in a total volume of $22 \mu \mathrm{l}$. The resulting hypoxanthine was separated from unchanged adenine by 
paper chromatography in water-saturated butan-1-ol on Whatman no. 1 paper, followed by elution of the hypoxanthine area and re-chromatography in the same system (yield, $21 \%$ ). Analysis by freeze-drying before and after

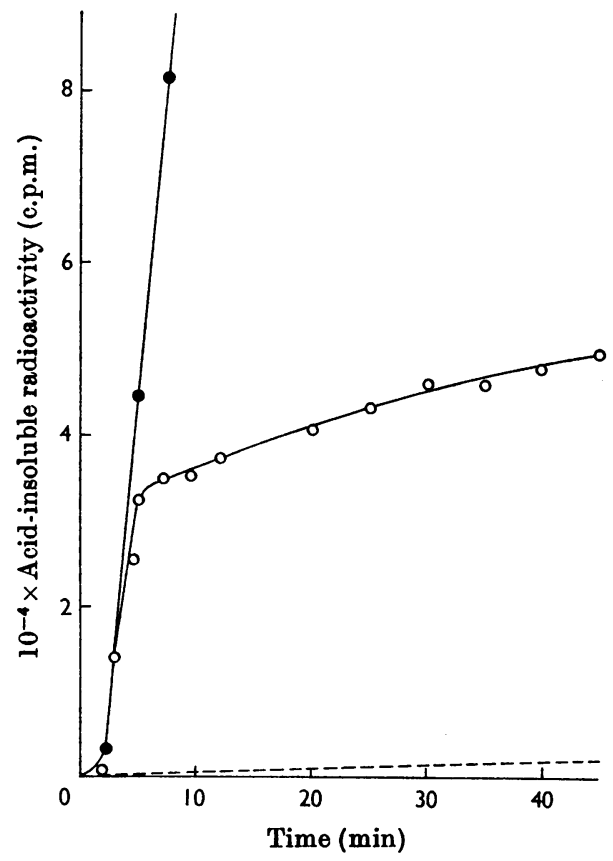

Fig. 2. Effects of guanosine and adenine on the incorporation of $\left[2-{ }^{14} \mathrm{C}\right]$ uracil $(4 \mu \mathrm{M} ; 54.9 \mathrm{Ci} / \mathrm{mol})$ by a pur $B^{-}$ gua $A^{-}$strain $\left(\mathrm{NE}-1 ; 5.0 \times 10^{11}\right.$ cells/l) into acid-insoluble material. Sample volumes were $0.5 \mathrm{ml}$. ๑, Adenine+ guanosine; $O$, guanosine; ----, no addition or hypoxanthine or adenine.

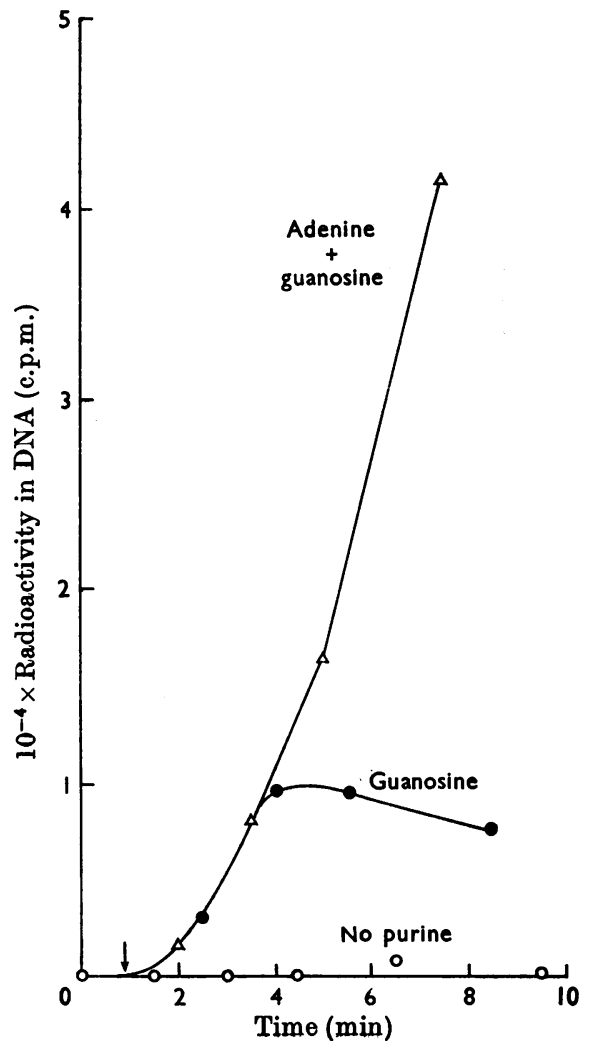

Fig. 4. Incorporation of $\left[2 .{ }^{14} \mathrm{C}\right]$ uracil $(4 \mu \mathrm{M} ; 54.9 \mathrm{Ci} / \mathrm{mol})$ into DNA by strain NE-1 $\left(5.8 \times 10^{11}\right.$ cells/1). The acidinsoluble material from $20 \mathrm{ml}$ samples was treated with $2 \mathrm{ml}$ of $\mathrm{M}-\mathrm{NaOH}$ for $18 \mathrm{~h}$ at $37^{\circ} \mathrm{C}$. DNA was precipitated by addition of $0.4 \mathrm{ml}$ of $5 \mathrm{M}-\mathrm{HCl}$ and $5 \mathrm{ml}$ of ethanol, collected on Oxoid membrane filters and the radioactivity was measured in Herberg's (1960) fluid. $O$, No purine added; $\bullet$, guanosine; $\Delta$, adenine+guanosine.

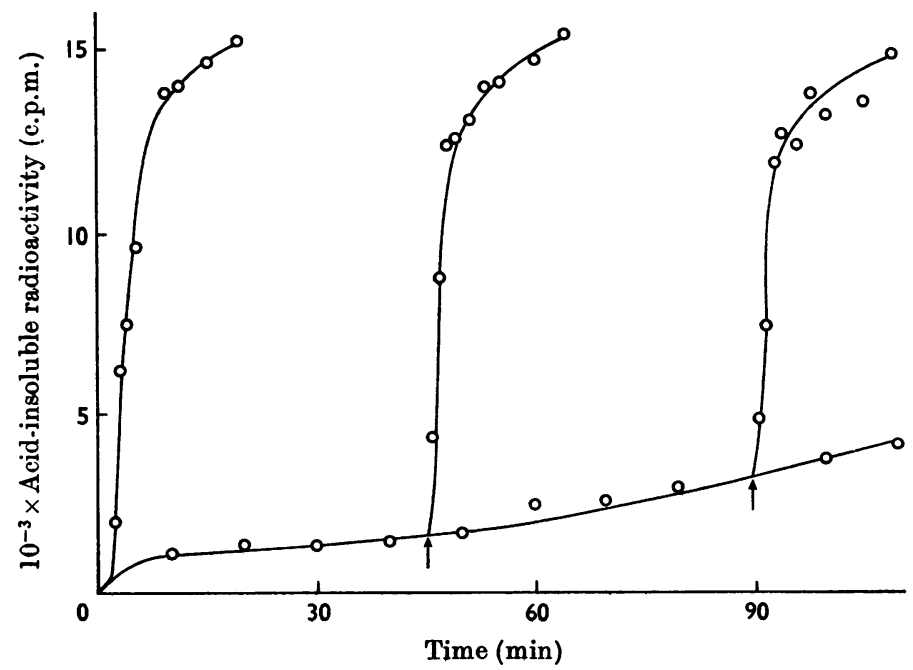

Fig. 3. Effects of guanosine on the incorporation of uracil after different periods of purine starvation. Details are as for Fig. 2 except that cell density was $2.0 \times 10^{11} / 1$. Guanosine was added at times indicated by arrows. 


\section{Table 2. Rates of incorporation of nucleic acid precursors}

The rates of incorporation into acid-insoluble material were measured for at least 2 min between 2 and 5 min after addition of the stimulatory purine compounds.

Radioactive precursor

$\left[2-{ }^{14} \mathrm{C}\right]$ Uracil

$\left[8-{ }^{3} \mathrm{H}\right]$ Guanosine

$\left[8-{ }^{14} \mathrm{C}\right] \mathrm{Hypoxanthine}$

\section{Conditions}

Guanosine alone or complete medium

No other purine source

No other purine source
Rate of incorporation

(mol/min per $10^{18}$ cells)

Strain NE-1 Strain AB-1325

$\begin{array}{ll}3.5 & 2.65 \\ 3.3 & 2.5 \\ - & 2.5\end{array}$

\section{Table 3. Incorporation of $\left[6-{ }^{3} \mathrm{H}\right]$ thymidine by strain $N E-1$ with different sources of purines}

Incorporation into acid-soluble material was measured at $20 \mathrm{~s}$ intervals after addition of $\left[{ }^{3} \mathrm{H}\right]$ thymidine $(0.17 \mu \mathrm{Ci} / \mathrm{ml} ; 20.5 \mathrm{Ci} / \mathrm{mol})$ to a culture $\left(4.8 \times 10^{11}\right.$ cells $\left./ 1\right)$, which was washed and transferred to fresh media at 0 min. The values are the radioactivity (c.p.m. at about $30 \%$ efficiency) incorporated by $1 \mathrm{ml}$ of culture between 0.3 and $1.3 \mathrm{~min}$ after the addition of thymidine. (The rate of incorporation was always virtually the same for at least 1 min further.)

\begin{tabular}{cccc} 
Time-period & \multicolumn{3}{c}{ Purine added } \\
(min) & $\begin{array}{c}\text { Adenine+ } \\
\text { guanosine }\end{array}$ & Guanosine & $\begin{array}{c}\text { No added } \\
\text { purine source }\end{array}$ \\
$0.3-1.3$ & 105 & 105 & 40 \\
$2.3-3.3$ & 270 & 250 & 50 \\
$4.3-5.3$ & 230 & 45 & 55 \\
$6.3-7.3$ & 270 & 48 & 52 \\
$8.3-9.3$ & 320 & 52 & 52 \\
$10.3-11.3$ & 350 & 52 & 55
\end{tabular}

autoclaving (Waterfield, Spanner \& Stanford, 1968) showed that the ratio of ${ }^{3} \mathrm{H}$ between the 2- and 8-positions was 1.5: 1 in both the adenine and the hypoxanthine. It is important to know this ratio because ${ }^{3} \mathrm{H}$ is lost from the 2-position in the IMP dehydrogenase step, when GMP is formed from IMP. The amounts of guanine nucleotides were therefore calculated from the radioactivity in the 8-position only.

\section{RESULTS}

Nucleic acid synthesis. The incorporation of uracil into acid-soluble material by strain AB-1325 $\left(\right.$ pur $\left.B^{-}\right)$is, of course, very low on transfer to purine-free medium. Guanosine and hypoxanthine can transiently restore the normal rate even though they are not converted into adenine nucleotides and so do not allow growth (Fig. 1). Guanosine acts in a similar manner in strain NE-1 (purBgua $A^{-}$) although, as expected from the lack of XMP aminase, hypoxanthine or xanthine do not (Fig. 2). The effect of guanosine on RNA synthesis still occurs after aeration in purine-free medium for as long as $90 \mathrm{~min}$ (Fig. 3).

Any incorporation into DNA is much smaller than that into RNA. There was appreciable transient synthesis of DNA when guanosine was added after only $1 \mathrm{~min}$ in purine-free medium (Fig. 4,
Table 3), but no incorporation of uracil was observed in other experiments when guanosine was added after $10 \mathrm{~min}$ of purine starvation. During this transient incorporation, guanosine (or hypoxanthine in strain AB-1325) are themselves incorporated at rates that are similar to the rate of incorporation of uracil (Table 2).

Purine nucleotide pools. The pools were analysed to determine if the nucleic acid synthesis occurred at the expense of intracellular adenine nucleotides. Cultures grown on radioactive purines were mixed with trichloroacetic acid, the acid-soluble nucleotides were separated on paper and their amounts were determined from their radioactivity. We could not filter or centrifuge the bacteria before extracting the nucleotides because the nucleotides were rapidly dephosphorylated. However, since the bacteria were transferred to fresh media at the start of each experiment, all the radioactivity was initially within the cells and we know that negligible amounts were lost into the media during the experimental periods.

As shown in Fig. 5, addition of hypoxanthine to a pur $B^{-}$strain caused a large decrease of ATP and a large increase of GTP. Changes of GDP and GMP were much smaller and so were the changes after the addition of adenine or during continued purine 

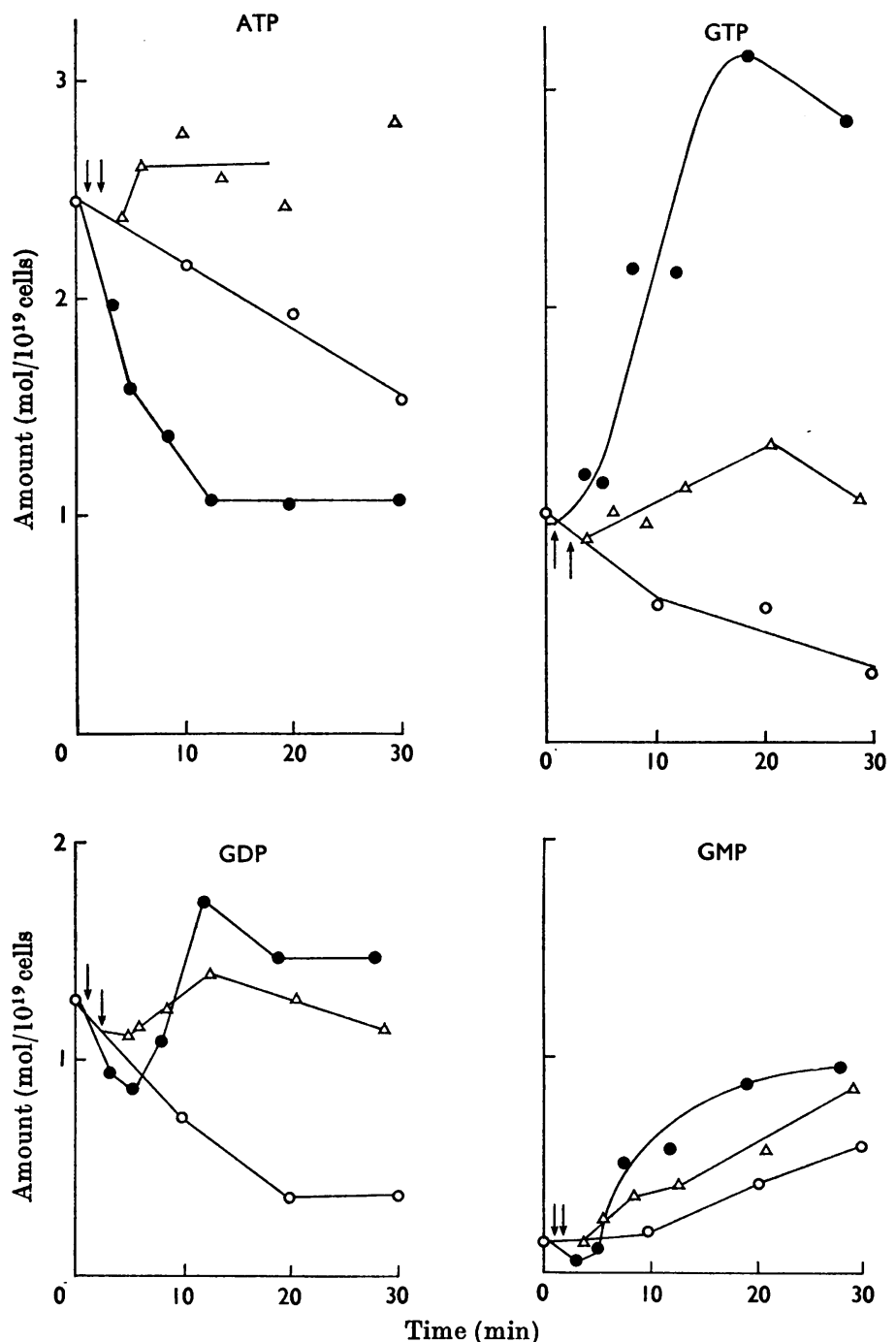

Fig. 5. Purine nucleotides in a purB- strain. Strain AB-1325 was grown with $\left[2,8{ }^{3} \mathrm{H}\right] \mathrm{adenine}(0.1 \mathrm{~mm}$; $2.598 \mathrm{Ci} / \mathrm{mmol}$ ) as the sole source of purines. It was harvested by Millipore filtration, resuspended in its original volume of purine-free medium $\left(5.6 \times 10^{10}\right.$ cells/l) and divided into three portions. [2,8. $\left.{ }^{3} \mathrm{H}\right] \mathrm{Hypoxanthine}$ $(46 \mu \mathrm{M} ; 2.598 \mathrm{Ci} / \mathrm{mmol})$ was added to one portion $(\bullet)$ at $\mathrm{l} \mathrm{min},\left[2,8-{ }^{3} \mathrm{H}\right]$ adenine to the second $(\Delta)$ at $2 \mathrm{~min}(\mathrm{see}$ arrows): $O$, no addition. Samples $(0.1 \mathrm{ml})$ were taken for determination of ATP, GTP, GDP and GMP.

starvation. In a similar manner, guanosine, when supplied by itself to strain NE-1 caused large decreases of ATP and ADP (Fig. 6). For this experiment, $\left[{ }^{14} \mathrm{C}\right]$ adenine was used and, because of the lower specific radioactivity, larger samples were taken. They were desalted before electrophoresis by adsorption to charcoal and subsequent elution (Cohn, 1963), a small amount of $\left[{ }^{3} \mathrm{H}\right]$ ATP being added to the samples so that the losses during desalting could be measured and corrected for.
The large and rapid decreases of adenine nucleotides in these experiments are comparable with the amounts of exogenous uracil or guanosine that are incorporated during the same period. Thus, when guanosine is supplied without adenine, both RNA and DNA are synthesized at the expense of endogenous ATP and ADP. The results are consistent with the view that GTP is the principal purine nucleotide that determines whether nucleic acids are synthesized or not. GDP is excluded by the 


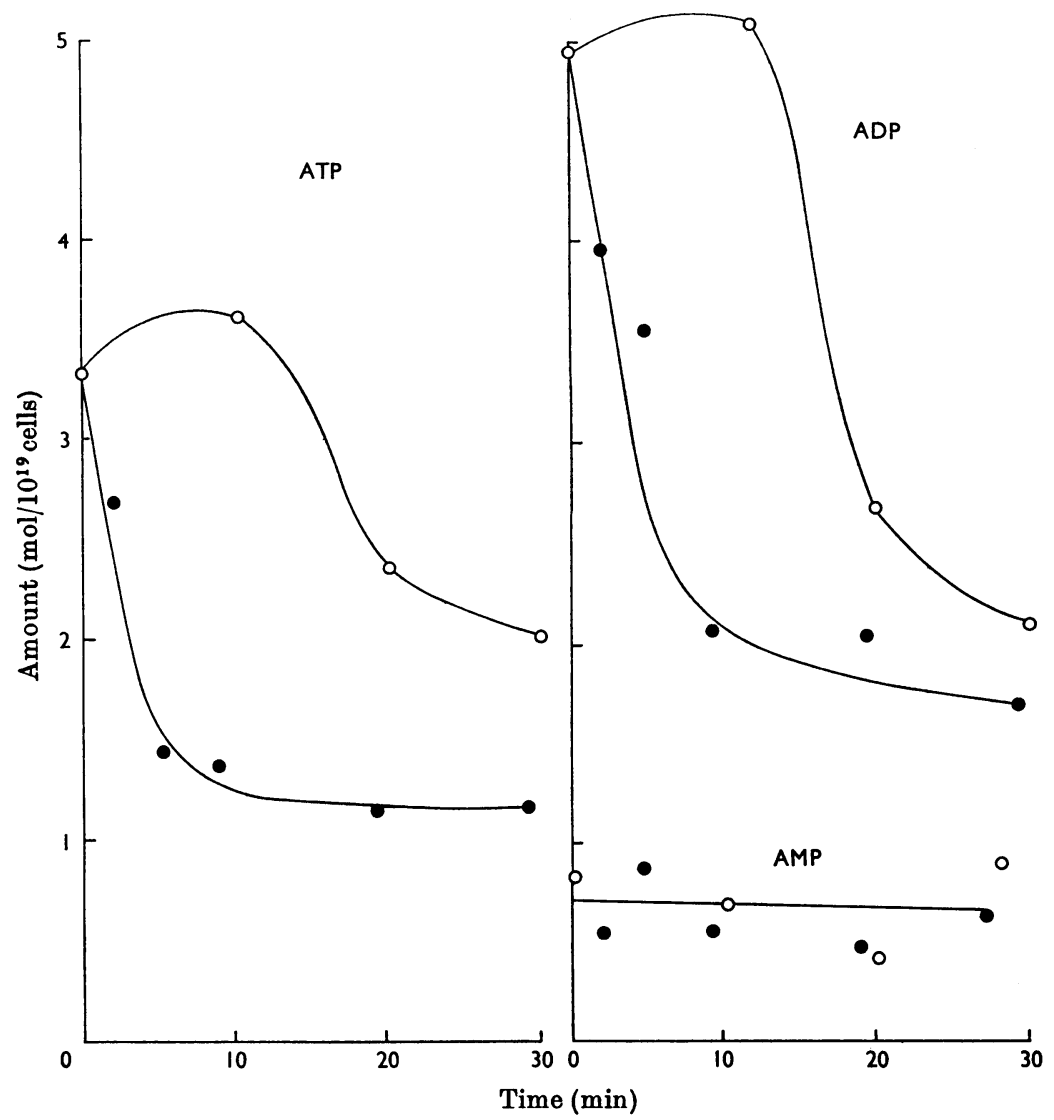

Fig. 6. Adenine nucleotides in strain NE-1 (purB- $\left.{ }^{-}, g u a A^{-}\right)$. Bacteria were grown with $\left[8-{ }^{14} \mathrm{C}\right] \mathrm{adenine}(14 \mu \mathrm{M}$; $35 \mathrm{Ci} / \mathrm{mol}$ ) as the sole source of purines, washed by filtration and resuspended in medium with no purines $(O)$. Guanosine $(10 \mu \mathrm{g} / \mathrm{ml})$ was added to part of the culture (๑) and $5.0 \mathrm{ml}$ samples were taken for analysis.

initial decrease shown in Fig. 5, when GTP is increasing rapidly as a result of supplying hypoxanthine. Nevertheless, if GTP is the controlling factor, the synthesis of nucleic acids must be sensitive to very small changes in the amount of GTP. A role for GMP cannot be entirely excluded although we have always seen much larger and more rapid changes of GTP than of GMP. Moreover, the different kinetics of the effects of adenine and hypoxanthine on RNA synthesis in strain AB-1325 are best correlated with their effects on the GTP content.

In an experiment with strain B.96 (purH $H^{-}$), starvation of adenine caused a decrease in GTP with little change of ATP. In addition there was a rapid increase of GDP and a restoration of the GTP content on addition of adenine. These increases of GDP and GTP were seen within $1 \mathrm{~min}$ at $25^{\circ} \mathrm{C}$ and they were followed by a very large increase of ATP to about five times the initial value
(Fig. 7). The initial content of ATP appeared to be regained between 10 and $20 \mathrm{~min}$ after addition of adenine.

We do not at present attach any significance to the actual distribution of nucleotides at the start of each experiment since we do not know if they are due to strain differences, to any effects of ${ }^{3} \mathrm{H}$-toxicity, or to unsuspected variations in the culture conditions. With the purH $H^{-}$strain, there is the added possibility that some ${ }^{3} \mathrm{H}$ was lost from the 2-position of the adenine nucleotides due to the action of IMP dehydrogenase. Nevertheless the changes observed in each of the various experiments are all consistent with our conclusion that GTP is more important in controlling nucleic acid synthesis than any of the other nucleotides that were measured.

Nicotinamide nucleotides. In all these experiments we observed only small changes in the amounts of adenine in the two spots derived from 


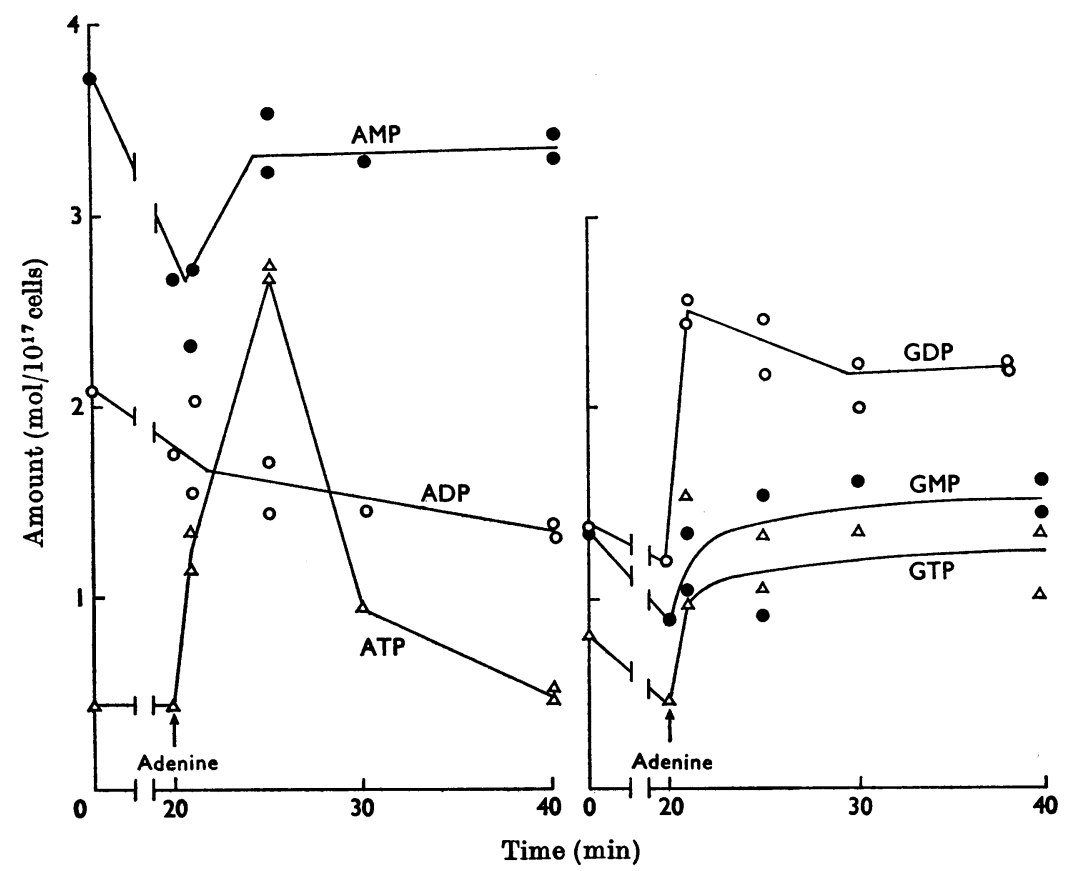

Fig. 7. Purine nucleotides in strain B-96 (purH $\left.{ }^{-}\right)$. Bacteria were grown with $\left[2,8 \cdot{ }^{3} \mathrm{H}\right] \mathrm{adenine}(25 \mu \mathrm{M}$; $980 \mathrm{Ci} / \mathrm{mol}$ ) to $10^{11}$ cells $/ 1$, washed by filtration and resuspended in purine-free medium for $20 \mathrm{~min}$. [ $\left[2,8-^{3} \mathrm{H}\right]-$ Adenine was then added to part of the culture (indicated by arrow) and $0.1 \mathrm{ml}$ samples were taken for analysis.

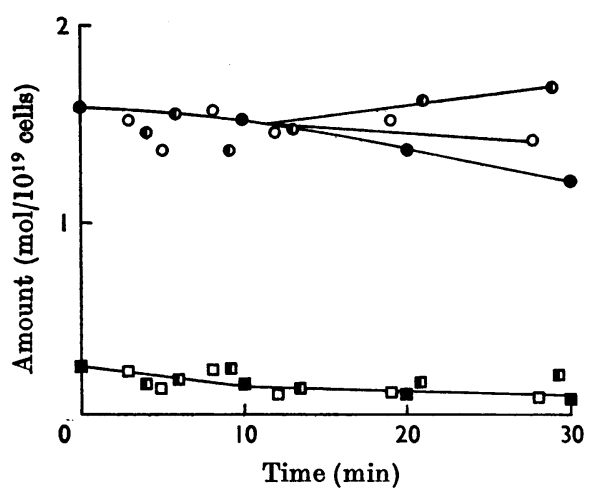

Fig. 8. Nicotinamide nucleotide contents. For details see Fig. 5. Circles $(O, \bullet, D)$ represent NAD values; $\square$, $\square$ and $\square$, values for NADP + ADP-ribose. $\bullet, \square$, No purine; $O, \square$, hypoxanthine; $\bigcirc$, adenine.

the nicotinamide nucleotides (Fig. 8). One of the spots was NAD and the second, with higher electrophoretic mobility, contained NADP as well as any adenine diphosphate ribose produced by the degradation of NADH. The amounts of NADP are known to be much less than those of NAD (London \& Knight, 1966) and so we can conclude that the nicotinamide nucleotides are not an important reservoir of adenine nucleotides for nucleic acid synthesis during adenine deficiency.

\section{DISCUSSION}

Significance of uracil incorporation into $R N A$. Although the incorporation of uracil into RNA is a useful indication of the rate of polymerization of nucleotides, it may not be an accurate measure of relative rates because of the extent to which exogenous uracil is diluted by endogenous pools or by the degradation products of unstable RNA. A conceivable treatment is to calculate the flux into RNA by assuming that the UTP entering RNA has the same specific radioactivity as the average of the internal UTP. However, this procedure is not valid because exogenous uracil does not mix completely with the internal pools and is used more readily for the synthesis of RNA than is most of the internal UTP (McCarthy \& Britten, 1962; Buchwald \& Britten, 1963; Mueller \& Bremer, 1968). In other words, exogenous uracil enters RNA by the small pool which has been termed the 'by-pass pool' by McCarthy \& Britten (1962).

We have not, therefore, attempted to convert the incorporation values into amounts of RNA synthesized, but we consider that it is reasonable 
to take the incorporation of uracil into RNA as being a measure of the net rate of RNA synthesis, particularly since the by-pass pool for uracil is very small and since the uptake of uracil appears to be closely regulated by the internal pool (McCarthy \& Britten, 1962; Buchwald \& Britten, 1963).

Nucleotide pools and $R N A$ synthesis. In our experiments, the endogenous GTP concentrations can be correlated with the net synthesis of RNA so long as the ATP concentration is not too low. Since purine nucleotides bind readily to membranes and membrane proteins (Weissbach, Redfield \& Kaback, 1969) small changes in total GTP might reflect large changes in the free GTP that is available for RNA synthesis. The nicotinamide nucleotides are not readily used as a reservoir of adenine.

We suggest that severe depletion of adenine nucleotides is normally avoided because the synthesis of RNA is more sensitive to changes in the content of GTP than to changes of ATP and also because adenine nucleotides are only converted into guanine nucleotides when adenine nucleotides are in excess and the guanine nucleotides are deficient (Magasanik \& Karibian, 1960). The route of this conversion is probably via hypoxanthine (Zimmerman \& Magasanik, 1964; Mans \& Koch, 1960). If so, the formation of hypoxanthine from AMP must be regulated very closely since we find that hypoxanthine is readily converted into GTP even when adenine nucleotides are deficient (Fig. 5). Nevertheless, there is probably a slow conversion of AMP into GTP in strain AB-1325 that is not possible in the strain NE-1, which lacks XMP aminase.

It is also noteworthy that in bacteria grown on adenine and fully adapted to it, adenosine acts more quickly than adenine in stimulating uracil incorporation. A probable explanation is that hypoxanthine is formed from adenine via AMP and adenosine, and that a measurable time is needed to activate the conversion of adenine into adenosine as the first steps to the formation of GTP.

There is a striking contrast between the relatively small changes of ATP and GTP in uncomplicated purine starvation of pur $B^{-}$or $p u r H^{-}$mutants and the very large decreases of UTP and CTP on pyrimidine starvation of a pyrimidine auxotroph (Lazzarini, Nakata \& Winslow, 1969).

G.A.T. thanks the Science Research Council for a Research Studentship and we all thank the Medical Research Council for generous support in the form of the Research Group on the Structure and Biosynthesis of Macromolecules. We also thank Dr J. S. Gots and Dr A. L. Taylor for bacterial strains.

\section{REFERENCES}

Buchwald, M. \& Britten, R. J. (1963). Biophys. J. 3, 155.

Burton, K. (1970). In Essays in Cell Metabolism, p. 67. Ed. by Bartley, W., Kornberg, H. L. \& Quayle, J. R. London: J. Wiley and Sons (Inc.) Ltd.

Cohn, W. E. (1963). Biochem. Prep. 10, 135.

Edlin, G. \& Stent, G. S. (1969). Proc. natn. Acad. Sci. U.S.A. 62,475 .

Gots, J. S. (1957). J. biol. Chem. 228, 57.

Gots, J. S. \& Goldstein, J. (1959). Science, N.Y., 130, 620.

Herberg, R. J. (1960). Analyt. Chem. 32, 42.

Jeffries, G. A. \& Burton, K. (1969). Biochem. J. 114, 42 P.

Lazzarini, R. A., Nakata, K. \& Winslow, R. M. (1969). J. biol. Chem. 244, 3092.

London, J. \& Knight, M. (1966). J. gen. Microbiol. 44, 241.

McCarthy, B. J. \& Britten, R. J. (1962). Biophys. J. 2, 35.

Magasanik, B. \& Karibian, D. (1960). J. biol. Chem. 235, 2672.

Mans, R. J. \& Koch, A. L. (1960). J. biol. Chem. 235, 450.

Mueller, K. \& Bremer, J. (1968). J. molec. Biol. 38, 329.

Pardee, A. B. (1955). J. Bact. 69, 233.

Rushizky, G. W. \& Knight, C. A. (1960). Virology, 11, 236.

Stone, A. B. \& Burton, K. (1962). Biochem. J. 85, 600.

Waterfield, W. R., Spanner, J. A. \& Stanford, F. G. (1968). Nature, Lond., 218, 472.

Weissbach, H., Redfield, B. \& Kaback, H. R. (1969). Archs Biochem. Biophys. 135, 66.

Zimmerman, E. F. \& Magasanik, B. (1964). J. biol. Chem. 239, 293. 